Jurnal Hukum Mimbar Justitia

Fakultas Hukum Universitas Suryakancana

Vol. 4 No. 1 - Juni 2018, hlm. 43-62

ISSN: 2477-5681 (Cetak), ISSN: 2580-0906 (Online)

Open Access at: https://jurnal.unsur.ac.id/jmj

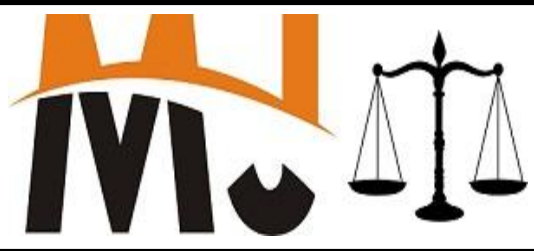

\title{
IMPLEMENTASI METODE BAGI HASIL DENGAN PRINSIP MUDHARABAH PADA BANK SYARIAH DI INDONESIA DIHUBUNGKAN DENGAN FATWA DSN NO. 15/DSN-MUI/IX/2000
}

\author{
Hermansyah \\ Prodi PPKn - Institut Pendidikan Indonesia Garut \\ Email : hermansyah@institutpendidikan.ac.id
}

Masuk: Maret 2018

Penerimaan: April 2018

Publikasi: Juni 2018

\begin{abstract}
ABSTRAK
Saat ini ekonomi syariah sudah mulai dikenal dan berkembang dalam kehidupan seharihari khususnya di Indonesia baik di sektor riil maupun di sektor keuangan. Salah satu lembaga keuangan yang berperan besar dalam memenuhi kebutuhan masyarakat adalah lembaga perbankan khususnya perbankan syariah. Landasan operasional bank syariah diatur dalam Undang-Undang No. 21 Tahun 2008 tentang Perbankan Syariah. Perkembangan sistem perbankan syariah dalam kerangka Dual Banking System memberikan alternatif lain dalam perbankan yang semakin lengkap bagi masyarakat Indonesia. Salah satu sistem operasional bank syariah adalah sistem bagi hasil. Penerapan sistem bagi hasil kepada shahibul maal dapat dilakukan dengan dua cara yaitu metode profit sharing dan revenue sharing. Penelitian ini menggunakan pendekatan yuridis normatif yang bertujuan untuk menemukan asas-asas hukum positif dan doktrin-doktrin hukum positif, bersifat deskriptif analitis. Tehnik pengumpulan data menggunakan studi kepustakaan dan studi lapangan, tehnik penentuan sampel secara purposive sampling dan analisa data menggunakan analisis normatif kualitatif. Dari penelitian dapat ditarik kesimpulan pertama dalam hukum ekonomi syariah sistem bagi hasil dengan menggunakan metode profit sharing dan revenue sharing diperbolehkan sesuai dengan prinsip syariah, kedua; aplikasi mudharabah dalam simpanan nasabah pada bank syariah mempunyai dua makna yaitu makna pertama mudharabah sebagai sebuah produk diterapkan dalam penghimpunan dana umumnya bank syariah menggunakan metode revenue sharing dan makna kedua mudharabah sebagai sebuah sistem dimana mudharabah menjadi pedoman umum bagi bank syariah dalam melakukan berbagai transaksi produk perbankan yang tersedia.
\end{abstract}

Kata kunci : Implementasi Metode Bagi Hasil, Prinsip Mudharabah, Bank Syariah, Fatwa DSN No. 15/DSN-MUI/IX/2000.

\section{ABSTRACT}

Today Islamic economy was recognized and growing in daily life, particularly Indonesia, both in real sector and financial sector. One of financial organization which has significant role in satisfying social need is bank, particularly Islamic bank. The 
operational base of Islamic bank was settled in Law No. 21 of 2008 about Islamic Bank. Dual banking system framework applied in Indonesia offer more alternatif option that can be chosed by Indonesian people. One of Islamic bank operational system is revenue sharing which can be applied in two method: profit sharing and revenue sharing. The research use a normative juridical approach that designed to find positive legal principles, analytical descriptive. The data collection techniques use literature study and field study, determination of sample in purposive sampling way and the data analysis using qualitative normative analysis. From research result can be conclused that first in law of Islamic economy, the profit sharing and revenue sharing methods is allowed by Islam law principle, second, application of mudharabah to customer savings in Islamic bank have two meanings; first, mudharabah as a product is applied to accumulation of funds, generally Islamic bank use revenue sharing and second, mudharabah as a system by which mudharabah is general guidelines for Islamic bank in performing various transaction of available banking product.

Keywords: The Implementation Of Profit Sharing Method, Mudharabah Principle, Islamic Bank, Fatwa DSN No. 15/DSN-MUI/IX/2000.

\section{PENDAHULUAN}

Islam adalah agama yang rahmatan lil'alamin, yang menjadi rahmat bagai semesta alam. Hal ini sesuai dengan ajaran yang diturunkan oleh Allah SWT, melalui Muhammad SAW yaitu ajaran Islam, sebagaimana dijelaskan dalam QS. Al Anbiya (21): 107 :

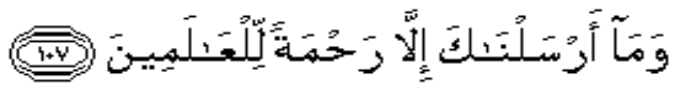

Artinya :

Dan tiadalah kami mengutus kamu (Muhammad), melainkan untuk menjadi rahat bagi semesta alam.

Ajaran pokok dalam Islam mengandung tiga aspek yang sangat fundamental yang meliputi aqidah, syariah dan akhlak. ${ }^{1}$ Menjalin proses diatas iman berlandaskan kepada aqidah, berpedoman syariah dibawah bimbingan akhlak. Al Qur'an tidak memuat berbagai aturan yang terperinci tentang syariah yang dalam sistematika hukum Islam terbagi menjadi dua bidang yaitu bidang ibadah dan muamalah.

The foundations of Islamic economics, the parent science of Islamic Banking, are based on the concepts of economic wellbeing, universal brotherhood and justice, equitable distribution of income, and freedom of

1 Tafsir QS:(2) ayat 177 dalam Muhammad Sayyid At-Thanthawi, terjemahan Sandi Rizky, 1997, At-Tafsir Al-Wasith li Al-Quran Al-Karim, Daar Nahdah Mishr, Cairo, Cet. 1, Terjemah oleh Sandi Rizki. 
Hermansyah

Jurnal Hukum Mimbar Justitia

Vol. 4 No. 1 - Juni 2018

the individual within the context of social welfare. Similarly, the foundations of Islamic Banking promote a balanced life between the life here and Hereafter. ${ }^{2}$

Sistem ekonomi syariah merupakan bagian dari sistem Islam yang mengatur masalah-masalah ekonomi agar berjalan dalam aturan syariah Islam. $^{3}$ Perbankan syariah merupakan salah satu bentuk implementasi dari ekonomi syariah. Dalam perspektif sistem perbankan ruang lingkup perbankan syariah bersifat universal yaitu meliputi kegiatan usaha komersial (commercial banking) dan investasi (investment banking). ${ }^{4}$

2 Tawfique Al-Mubarak, Noor Mohammad Osmani, 2010, Applications of Maqasid alShari'ah and Maslahah in Islamic Banking practices: An analysis, International Seminar on Islamic Finance in India, 4 - 6 October, Kochi, India. (Unpublished), hIm. 6-7

3 Veithzal Rivai, Andi Buchari, 2009, Islamic Economics; Ekonomi Syariah Bukan Opsi Tetapi Solusi, Bumi Aksara, Jakarta, hlm. 20.

4 Achmad Baraba, 1999, Prinsip Dasar Operasional Perbankan Syariah, Buletin Ekonomi Moneter dan Perbankan, Vol.2 No.3, 1999 hlm. 5 lihat juga Setiawan Budi Utomo, 2011, Kajian Hukum Atas Keabsahan Produk Perbankan Syariah Dikaitkan Dengan Fatwa DSN Dalam Tujuan Negara Keadilan, Disertasi, Fakultas Hukum Unpad, hlm.7.
Adanya ketentuan dalam UndangUndang No. 10 Tahun 1998 sebagai amandemen atas Undang-Undang No. 7 Tahun 1992 tentang Perbankan, yang membolehkan bank konvensional untuk membuka unit usaha syariah maupun office channeling dan dikeluarkannya Undang-Undang No. 21 Tahun 2008 tentang Perbankan Syariah, menunjukkan bahwa instrumen ekonomi syariah ini mendapat perhatian yang memadai dari pelaku ekonomi di tanah air. ${ }^{5}$ Hal ini juga merupakan manifestasi dari tanggung jawab negara untuk mewujudkan keadilan sosial, kesejahteraan umum, dan sebesarbesarnya untuk kemakmuran rakyat dengan mengeluarkan regulasi di bidang perbankan dan perbankan syariah.

Menurut Yusuf Qardhawi, hikmah eksplisit yang tampak jelas di balik pelarangan riba adalah perwujudan persamaan yang adil di antara pemilik modal dengan usaha, serta pemikulan risiko dan akibatnya secara berani dan penuh rasa tanggungjawab. Prinsip keadilan dalam Islam ini tidak memihak kepada salah

5 Ali Hasan, 2010, Marketing Bank Syariah, Bandung, Ghalia Indonesia, hlm. 1. 
Hermansyah

Jurnal Hukum Mimbar Justitia

Vol. 4 No. 1 - Juni 2018

satu pihak tetapi keduanya berada dalam posisi yang sama. ${ }^{6}$

Perbankan syariah mempunyai begitu banyak pilihan dalam memfasilitasi kebutuhan pengusaha dan nasabah akan sarana pembiayaan. Sedangkan perbankan konvensional hanya mempunyai beberapa variasi pilihan pembiayaan. ${ }^{7}$ Sistem ekonomi syariah menggunakan bagi hasil dan tidak menggunakan sistem bunga, hal ini didasarkan pada ayat-ayat Al-qur'an yang mendasarinya. ${ }^{8}$

Prinsip syariah yang dimaksud dalam operasional perbankan syariah merupakan prinsip hukum Islam dalam kegiatan perbankan berdasarkan fatwa yang dikeluarkan oleh lembaga yang memiliki kewenangan dalam penetapan fatwa di bidang syariah. ${ }^{9}$ Fatwa berasal

\section{Idem, hlm. 17.}

7 Dwi Agung Nugroho Arianto, 2011, Peranan Al Mudharabah Sebagai Salah Satu Produk Perbankan Syariah Dalam Upaya Mengentaskan Kemiskinan Di Indonesia, Jurnal Ekonomi \& Pendidikan, Volume. 8 Nomor. 2, November 2011, hlm. 167.

8 Muhammad, 2002, Manajemen Bank Syari'ah, Jogjakarta, (UPP) AMP YKPN, hlm. 103.

9 Pasal 1 penjelasan umum angka 12 Undangundang No. 21 Tahun 2008 tentang Perbankan Syariah. Dalam Pasal 26 ditegaskan bahwa prinsip syariah difatwakan oleh Majelis Ulama Indonesia yang dituangkan dalam Peraturan Bank Indonesia. dari kata Arab al-fatwa atau al-futya yang artinya jawaban terhadap persoalan hukum Islam. Salah satu prinsip syariah adalah adanya prinsip bagi hasil yang dalam implementasi bank syariah dilakukan berdasarkan akad mudharabah dan musyarakah. ${ }^{10}$ Menurut Neneng Nurhasanah, mudharabah ternasuk kedalam hubungan muamalah yang menyangkut kebendaan dan sudah ada sebelum Nabi Muhammad SAW diangkat menjadi rasul, yang kemudian kebolehannya ditetapkan dalam Islam. ${ }^{11}$

Berdasarkan latar belakang di atas maka permasalahan yang diidentifikasikan sebagai berikut : 1 .

10 Umi Karomah Yaumiddin, 2010, Usaha Bagi Hasil Antara Teori Dan Praktek, Bantul, Kreasi Wacana, hlm. 3. Memberikan definisi bagi hasil adalah sebuah usaha yang dibangun berdasarkan kesepakatan antara pemodal dan pengusaha untuk memberikan pembagian hasil berdasarkan persentase tertentu dari hasil usaha. Kesepakatan ini dilakukan secara adil artinya setiap mutra mendapatkan bagi hasil sesuai dengan kontribusi yang diberikannya baik modal, keterampilan maupun tenaga dan transparan yang berarti bahwa pemodal dan pengusaha saling mengetahui jumlah bagi hasil yang diperolehnya dan progres usaha itu sendiri.

11 Hermansyah, dan Sandi Rizki Febriadi, 2017, Implementasi Akad Mudharabah Pada Bank Syariah Dihubungkan Dengan Pasal 1338 KUH Perdata, Prosiding SNaPP Sosial, Ekonomi dan Humaniora, Vol. 7, No.2, Oktober, hlm. 436. 


\section{Hermansyah \\ Jurnal Hukum Mimbar Justitia \\ Vol. 4 No. 1 - Juni 2018}

Bagaimana kesesuaian dan pengaturan metode bagi hasil dengan prinsip mudharabah pada bank syariah di Indonesia?; 2. Bagaimana implementasi metode bagi hasil dengan prinsip mudharabah pada Bank Syariah di Indonesia dihubungkan dengan Fatwa Dewan Syariah Nasional Nomor 15/DSN-MUI/IX/2000?.

\section{METODE PENELITIAN}

Dalam penelitian ini penulis menggunakan metode pendekatan yuridis normatif, yang bertujuan untuk menemukan asas-asas hukum positif dan doktrin-doktrin hukum positif. ${ }^{12}$ Penelitian ini bersifat deskriptif analitis Sedangkan tehnik pengumpulan data menggunakan tehnik studi kepustakaan (Library Reseach) dan studi lapangan. Studi kepustakaan (Library Reseach) adalah tehnik untuk mendapatkan data teoritis guna memperoleh pendapat para ahli dan teorinya melalui sumber bacaan atau disebut penelitian terhadap data sekunder. Pengambilan sampel yang dilakukan oleh penulis adalah secara purposive sampling yaitu sampel yang dipilih dengan cermat sehingga relevan

12 Soerjono Soekanto, 1986, Pengantar Penelitian Hukum, Jakarta, UI Press, hlm. 10. dengan penelitian. Peneliti akan berusaha agar dalam sampel itu terdapat wakil-wakil dari segala lapisan populasi. $^{13}$ Tehnik yang digunakan dalam menganalisa data adalah analisis normatif kualitatif. ${ }^{14}$

\section{HASIL PENELITIAN DAN ANALISIS}

Ekonomi Islam di Indonesia yang lazim dikenal dengan istilah ekonomi syariah merupakan bagian integral dari ajaran Islam. Secara garis besar ajaran Islam dikelompokan ke dalam tiga bagian yaitu aqidah, akhlak dan syariah. Dimana aspek syariah dibagi lagi kedalam dua bagian yaitu bidang ibadah dan bidang muamalah. Bidang ibadah menekankan kepada seluruh aspek yang berkaitan dengan penghambaan diri kepada Allah SWT, sedangkan bidang muamalah berkaitan dengan hubungan antara manusia dengan sesamanya sebagai implementasi dari hablum minannas yaitu hubungan antara

13 Nasution, 2011, Metode Research, Cetakan ke duabelas, Bumi Aksara, Jakarta, hlm. 98.

14 Ronny Hanitijo Soemitro, 1988, Metodologi Penelitian Hukum dan Jurimetri, Ghalia Indonesia, Semarang, hlm. 98. 
Hermansyah

Jurnal Hukum Mimbar Justitia

Vol. 4 No. 1 - Juni 2018

manusia dengan manusia yang merupakan perintah dari Allah SWT. ${ }^{15}$

Sistem ekonomi syariah atau ekonomi Islam merupakan bagian dari sistem Islam yang mengatur masalahmasalah ekonomi agar berjalan dalam aturan syariah Islam. Pengertian sistem ekonomi terletak pada aturan keseluruhan yang menentukan langkahlangkah ekonomi bagi semua unit ekonomi yang ada dalam suatu masyarakat atas dasar prinsip-prinsip tertentu dan untuk mencapai tujuan tertentu.

Pengertian ekonomi sebagai suatu sistem mencakup tiga komponen pokok yang harus dimiliki yaitu : ${ }^{16}$

1. Prinsip dasar atau sistem nilai yang melandasi segala kegiatan ekonomi yang dilaksanakan oleh setiap unit ekonomi;

2. Adanya tujuan atau cita-cita yang hendak dicapai;

3. Adanya patokan yang menyeluruh yang mengatur operasi unit-unit yang ada.

15 Hamid Arfin, 2007, Hukum Ekonomi Islam (Ekonomi Syariah) Indonesia, Makasar, Ghalia Indonesia, hIm. 36.

16 Veithzal Rivai, Andi Buchari, 2009, Islamic Economics; Ekonomi Syariah Bukan Opsi Tetapi Solusi, Bumi Aksara, Jakarta, hlm. 20.
Sistem ekonomi syariah mempunyai ciri-ciri sebagai berikut: ${ }^{17}$

1. Ekonomi syariah merupakan bagian dari sistem syariah secara keseluruhan dan keyakinan merupakan satu bagian saja dari sistem syariah. Oleh sebab itu hubungan ekonomi syariah dengan akidah serta syariat menyebabkan kegiatan ekonomi dalam syariah berbeda dengan aktivitas ekonomi yang diciptakan manusia.

2. Ekonomi syariah merealisasikan keseimbangan antara kepentingan individu dan masyarakat, hal ini sesuai dengan cita-cita ekonomi syariah yaitu untuk merealisasikan kekayaan dan kesejahteraan hidup dan keuntungan umum bagi masyarakat, bukan untuk menciptakan persaingan dan monopoli serta sikap mementingkan diri sendiri.

Terkandung dua aspek yang saling berhubungan dalam praktek perbankan syariah yaitu aspek syariah dan aspek komersial atau aspek bisnis. Penerapan aspek syariah secara murni

17 Hulwati, 2006, Ekonomi Islam, Padang, Ciputat Press, Jakarta, hlm. 11-12. 
Hermansyah

Jurnal Hukum Mimbar Justitia

Vol. 4 No. 1 - Juni 2018

untuk saat ini sepertinya belum bisa dilaksanakan karena para pelaku perbankan syariah masih banyak yang mempergunakan tata cara ekonomi perbankan yang menyerupai sistem perbankan secara konvensional. Di sisi lain apabila pelaksanaan perbankan syariah hanya memperhatikan aspek bisnis saja tanpa memperhatikan aspek syariah sama saja dengan melakukan praktek perbankan secara konvensional dengan kemasan akad syariah atau dengan kata lain hanya ganti menggunakan baju syariah.

Asas-asas tersebut di atas diwujudkan dalam konsep bagi hasil yang dilaksanakan oleh operasional perbankan syariah yang sesuai dengan mekanisme ekonomi Islam dan berbeda dengan mekanisme dalam sistem perbankan konvensional yang menggunakan instrumen bunga. Prinsip keadilan dalam Islam ini tidak memihak kepada salah satu pihak melainkan keduanya berada pada posisi yang seimbang. Prinsip keadilan termasuk kedalam salah satu tujuan dari hukum Islam atau maqasid syariah, hal ini sejalan dengan apa yang dikatakan oleh N.E. Algra dan H.C.J.G. Jansen, sasaran dari negara hukum adalah terciptanya kegiatan kemasyarakatan yang bertumpu pada keadilan dan kemanfaatan. $^{18}$ Hal ini sebagaimana dikatakan oleh A. Zaki Yamani, bahwa salah satu pokok dari tujuan syari'at Islam adalah untuk merealisasikan kemaslahatan manusia yang bertumpu pada nilai-nilai keadilan sosial. ${ }^{19}$

Agar penerapan ekonomi syariah sesuai dengan apa yang diharapkan yaitu adanya ketertiban dan keteraturan dalam melakukan kegiatan ekonomi, maka perlu satu aturan atau kaidah yang mengatur tentang perekonomian secara menyeluruh yaitu harus adanya kaidah hukum.

Menurut Purwosucipto, dalam hukum positif di Indonesia hukum diartikan sebagai keseluruhan norma yang oleh penguasa negara atau penguasa masyarakat yang berwenang menetapkan hukum dinyatakan atau dianggap sebagai peraturan yang

18 Mia Amalia, 2016, Analisis Terhadap Tindak Pidana Prostitusi Dihubungkan Dengan Etika Moral Serta Upaya Penanggulangan Dikawasan Cisarua Kampung Arab, Jurnal Hukum Mimbar Justitia Fakultas Hukum Universitas Suryakancana, Vol. 2, No. 2, Edisi Desember, hlm. 869.

19 Walim, 2017, Prinsi, Asas dan Kaidah Hukum Waris Islam Adil Gender, Jurnal Mimbar Justitia Fakultas Hukum Universitas Suryakencana, Vol. 3, No. 1, Edisi Juni, hlm. 36. 
Hermansyah

Jurnal Hukum Mimbar Justitia

Vol. 4 No. 1 - Juni 2018

mengikat bagi sebagian atau seluruh anggota masyarakat dengan tujuan untuk mengadakan suatu tata yang dikehendaki oleh penguasa tersebut. ${ }^{20}$

\section{Sementara menurut Toto Tohir}

Suriaatmadja, hukum Islam di Indonesia selain yang berlaku karena peraturan perundang-undangan mengatur atau menunjuk kaidah hukum Islam, terdapat juga hukum Islam yang berlaku karena kebutuhan masyarakat. Walaupun belum diatur dalam perundang-undangan, kebutuhan nyata masyarakat sering pula menjadikan suatu kaidah hukum Islam berlaku dengan sendirinya, seperti perserikatan yaitu mudharabah/musyarakah, gadai serta hipotek. ${ }^{21}$

Berkaitan dengan kegiatan ekonomi khususnya ekonomi syariah maka hukum ekonomi syariah adalah seperangkat aturan atau norma yang menjadi pedoman baik oleh perorangan atau badan hukum dalam melaksanakan kegiatan ekonomi yang bersifat privat

20 Veithzal Rivai, Andi Buchari, Op. Cit., hlm 355.

21 Toto T Suriaatmadja, 2004, Kontribusi Hukum Islam Dalam Pembentukan Hukum Nasional Menuju Masyarakat Madani, Jurnal Syiar Madani, Vol. 6, No. 1, hlm. 48. maupun publik berdasarkan prinsip syariah Islam. $^{22}$

Dengan memperhatikan nilai ibadah dalam bidang muamalah dan juga kaidah hukum yang ditetapkan dalam syariat berarti semua jenis muamalah yang dilakukan oleh seorang muslim dengan muslim yang lainnya merupakan pengabdian diri, ibadah kepada Allah SWT. dan senantiasa mempunyai keyakinan bahwa Allah SWT. senantiasa mengawasi setiap gerak langkahnya. ${ }^{23}$

Implikasinya semua aktivitas keduniaan yang dilakukan mesti mempertimbangkan akhirat sebagaimana firman Allah SWT. dalam Al-Quran surat Al-Qashas ayat (77) yang berbunyi :

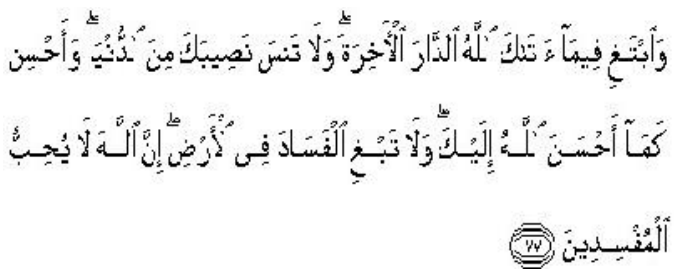

“Dan carilah harta kekayaan yang telah dikaruniakan Allah kepadamu untuk tujuan pahala dan kebahagiaan hari akhirat dan janganlah engkau melupakan keperluanmu didunia dan berbuat baiklah kepada hamba-hamba Allah, sebagaimana Allah telah berbuat baik kepadamu. Dan janganlah kamu

$\begin{array}{ll}22 & \text { Idem, hlm. } 356 . \\ 23 & \text { Hulwati, Op Cit, hlm. } 19 .\end{array}$ 
Hermansyah

Jurnal Hukum Mimbar Justitia

Vol. 4 No. 1 - Juni 2018

berbuat kerusakan di muka bumi, sesungguhnya Allah tidak suka kepada orang-orang yang berbuat kerusakan."

Ayat tersebut menegaskan supaya harta yang diberikan Allah SWT kepada kita supaya diberikan kepada orangorang yang memang membutuhkan dan janganlah melakukan sesuatu yang merusak masyarakat. Keistimewaan dari ajaran yang terkandung dalam muamalah adalah $:{ }^{24}$

1. Berdasarkan kepada gambaran kehidupan yang jelas;

2. Memberi kesejahteraan dan keadilan kepada semua pihak yang terlibat dalam perdagangan;

3. Menegaskan konsep perkongsian untung dan rugi dan juga penagihan pendapatan dan kekayaan kepada semua lapisan masyarakat;

4. Tasawwur keimanan yang jelas dapat mengawal bentuk aktivitas yang selaras dengan kelangsungan hidup manusia yang berakhlak dan bermartabat.

Hakekat dari kehidupan manusia adalah adanya saling ketergantungan dan saling membutuhkan satu dengan yang lainnya. Untuk itu seorang muslim

24 Idem, hlm. 20. diwajibkan untuk saling membantu dan menolong antar sesamanya, sebagaimana disebutkan dalam AlQuran surat Al-Maidah ayat (2), yang berbunyi :

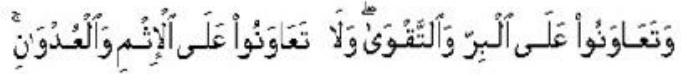

.....dan tolong menolonglah kamu dalam (mengerjakan) kebajikan dan taqwa dan jangan tolong menolong dalam berbuat dosa dan pelanggaran...

Kaidah umum dalam mencari nafkah adalah bahwa Islam tidak memperbolehkan para penganutnya mendapatkan harta dengan cara semaunya. $^{25} \quad$ Untuk mencari penyelesaian dalam persoalan ini maka para ahli ekonomi khususnya ekonomi syariah mencoba mengembangkan sistem keuangan syariah yaitu sistem keuangan tanpa bunga dan berbasis bagi hasil mudharabah.

Sistem ini akan dapat memberikan penyelesaian dan kemaslahatan terhadap masyarakat terutama sekali bagi umat Islam. $^{26}$ Mudharabah termasuk kedalam salah satu maqashid syariat yaitu kemaslahatan yang meliputi aspek jalbiyyah yaitu

\footnotetext{
25 Yusuf Qardhawi, 2007, Halal Haram Dalam Islam, Era Intermedia, hlm. 210.

26 Hulwati, Op. Cit., hlm. 62.
} 
Hermansyah

Jurnal Hukum Mimbar Justitia

Vol. 4 No. 1 - Juni 2018

mendorong untuk mengembangkan agar lebih baik produktif dapat bermanfaat bagi yang membutuhkan dan aspek salbiyyah yaitu menjaga agar tidak menimbulkan kemufsadatan atau menimbulkan hal yang negatif. ${ }^{27}$

\section{Menurut Izzudin bin Abd al-}

Salam di dalam kitabnya Qawa'id alAhkam fi Mushalih al-Anam, menyatakan bahwa seluruh syariah itu adalah maslahat baik dengan cara menolak mafsadah atau dengan meraih maslahat. ${ }^{28}$ Kaidah fiqih yang menyatakan: Apabila di antara yang maslahat itu banyak dan harus dilakukan salah satunya pada waktu yang sama, maka lebih baik pilih yang paling maslahat.

Akad mudharabah diperbolehkan dalam hukum Islam karena bertujuan untuk saling membantu antara pemilik modal dan seseorang yang ahli dalam melakukan usaha. Berdasarkan teori perbankan syariah kontemporer prinsip mudharabah dijadikan sebagai alternatif

27 Wawancara dengan Rachmat Syafei, Ketua Bidang Syariah Majelis Ulama Indonesia Jawa Barat, tanggal 2 Januari 2012, pukul 15.45-16.15 WIB.

28 Izzudin bin 'Abd al-Salam, 2006, Qawa'id alAhkam fi Mashalih al-Anam, (t.t.:Dar al-Jail), Juz I, hlm.11 dalam H.A. Djazuli, KaidahKaidah Fiqih, Kencana Prenada Media Group, Jakarta, hlm. 27. penerapan sistem bagi hasil. Meskipun demikian dalam prakteknya mekanisme bagi hasil dalam memainkan operasional investasi dana bank peranannya sangat lemah hal ini dikarenakan standar moral yang lemah, ketidak efektifan model pembiayaan bagi hasil, berkaitan dengan para pengusaha, segi biaya, segi teknis, kurang menariknya sistem bagi hasil dalam aktivitas bisnis dan permasalahan efisiensi. $^{29}$

Dalam kontrak mudharabah kesepakatan atas nisbah dalam pembagian hasil usaha harus disepakati oleh para pihak yang mengadakan kontrak. Tingkat pembagian tersebut harus berdasarkan kepada rasio prosentase dan bukan dengan jumlah nominal yang sudah ditentukan. Shahibul maal dalam hal ini nasabah pemilik dana simpanan pada bank syariah hanya akan menanggung kerugian sebesar dana yang sudah diinvestasikan, sedangkan risiko

29 Muhammad, 2008, Manajemen Pembiayaan Mudharabah di Bank Syariah, RajaGrafindo, Jakarta, hlm. 47. Lihat juga Osmad Muthaher, 2012, Akuntansi Perbankan Syariah, Graha Ilmu, Yogyakarta, $\mathrm{hlm}$. 45-49. Bandingkan dengan Muhammad Yusuf, Wiroso, 2011, Bisnis Syariah, Mitra Wacana Media, Jakarta, hlm. 92-93. 
Hermansyah

Jurnal Hukum Mimbar Justitia

Vol. 4 No. 1 - Juni 2018

mudharib yaitu bank syariah hanya menanggung risiko atas kegagalan pengelolaan dana mudharabah saja dan tidak harus bertanggungjawab untuk mengembalikan dana tersebut.

Dalam hal ini bank syariah bertindak sebagai mudharib atau pengelola dana, sedangkan nasabah bertindak sebagai shahibul mal atau pemilik dana. Bank syariah dalam kapasitasnya sebagai mudharib, mempunyai kuasa untuk melakukan berbagai macam usaha yang tidak bertentangan dengan prinsip syariah serta mengembangkannya termasuk melakukan akad mudharabah dengan pihak lain. Namun disisi lain bank syariah juga memiliki sifat sebagai seorang wali amanah yang berarti bank harus berhati-hati serta bijaksana dan mempunyai itikad dan bertanggung jawab atas segala sesuatu yang timbul akibat kesalahan atau kelalainnya. Dari hasil pengelolaan dana mudharabah, bank syariah akan memberikan bagi hasil kepada pemilik dana sesuai dengan nisbah yang telah disepakati dalam akad pembukaan rekening.

Dalam mengelola dana tersebut bank tidak bertanggung jawab terhadap kerugian yang bukan disebabkan kelalainnya, tetapi apabila yang terjadi adalah mis magement, maka bank harus bertanggung jawab penuh atas kerugian tersebut. Biaya yang dikeluarkan dalam pengelolaan dana nasabah menjadi tanggung jawab bank syariah yang diambil dari nisbah keuntungan yang menjadi haknya. Disamping itu bank syariah tidak diperkenankan untuk mengurangi nisbah keuntungan nasabah penabung tanpa persetujuan dari nasabah yang bersangkutan. Apabila mudharib dalam hal ini bank syariah melakukan pelanggaran atas setiap kesepakatan terhadap akad mudharabah maka kerugian yang timbul harus menjadi tanggungjawab mudharib.

Kerjasama mudharabah dapat juga dikatakan sebagai akad yang membatasi manajemen shahibul maal dalam proyek dan sebaliknya mudharib mempunyai pertanggung jawaban yang luas dalam pengelolaan dana. Setiap tindakan mudharib yang sesuai dengan isi dalam akad mudharabah dan tidak melakukan kesalahan dalam penggunaan dan pengaturan modal yang diserahkan kepadanya menjadikan shahibul maal harus menanggung kerugian apabila proyek usahanya 
Hermansyah

Jurnal Hukum Mimbar Justitia

Vol. 4 No. 1 - Juni 2018

mengalami kerugian. ${ }^{30}$ Pasal dan ayat dalam Undang-Undang No. 21 Tahun 2008 yang mencantumkan konsep mudharabah sebagai istilah teknis perbankan syariah adalah Pasal 1 ayat (21), (22), (24), (25) huruf a, Pasal 19 ayat (1) huruf b,c,i, Pasal 19 ayat (2) huruf b,c,i, Pasal 21 huruf c. Empat ayat dalam Pasal 21 menerangkan mudharabah sebagai dasar akad simpanan dan investasi berupa tabungan, giro, deposito dan dasar dalam akad pembiayaan. Keempat ayat dalam Pasal 1 di spesifikasikan oleh Pasal 19 dan Pasal 21. Pasal 19 ayat (1) huruf $b$ tentang penghimpunan dana bagi Bank Umum Syariah (BUS), Pasal 21 ayat (1) huruf $\mathrm{c}$ dan i tentang penyaluran pembiayaan bagi bank umum syariah, Pasal 19 ayat (2) huruf b tentang penghimpunan dana oleh unit usaha syariah dan Pasal 21 huruf a angka 2 dan huruf $\mathrm{b}$ angka 1 dan huruf $\mathrm{c}$ yang masing-masing tentang penghimpunan dana, penyaluran pembiayaan dan menempatkan dana bank pada bank syariah lain bagi BPRS.

30 Muhammad, Idem, hlm. 36. Bandingkan dengan M. Syafi'i Antonio, 2001, Bank Syariah; Dari Teori ke Praktik, Gema Insani, Jakarta, hlm. 97.
Berdasarkan ketentuan yang terdapat pada pasal dan ayat tersebut di atas terlihat bahwa transaksi mudharabah merupakan landasan yuridis perbankan syariah dalam melakukan kegiatan usaha, baik kegiatan penghimpunan dana maupun menyalurkan pembiayaan. Penghimpunan dana menyangkut simpanan berupa deposito dan tabungan sementara penyaluran dana berupa penyaluran pembiayaan bagi hasil.

Secara umum substansi ketentuan deposito dan tabungan mudharabah sesuai dengan Fatwa Dewan Syariah Nasional (DSN-MUI) dan ketentuan yang terdapat dalam Pasal 5 ayat (3) Peraturan Bank Indonesia No. 7/46/PBI/2005 tentang akad penghimpunan dan penyaluran dana bagi bank yang melaksanakan kegiatan usaha berdasarkan prinsip syariah, Pasal 3 huruf (a) Peraturan Bank Indonesia No. 9/19/PBI/2007 tentang pelaksanaan prinsip syariah dalam kegiatan penghimpunan dana dan penyaluran dana serta pelayanan jasa bank syariah dan Surat Edaran Bank Indonesia No. 10/14/DPbs tanggal 17 Maret 2008 tidak jauh berbeda. Ketentuan yang terdapat dalam Fatwa Dewan Syariah 
Hermansyah

Jurnal Hukum Mimbar Justitia

Vol. 4 No. 1 - Juni 2018

Nasional Majelis Ulama Indonesia, baik untuk tabungan mudharabah Fatwa No. 2/DSN-MUI/IV/2000 tanggal 1 April 2000 tentang Tabungan maupun deposito mudharabah Fatwa No. 3/DSN-MUI/IV/2000 tanggal 1 April 2000 tentang Deposito sama-sama memuat enam ketentuan yang berisi sama, tetapi yang membedakan hanya dari sisi nomor fatwa saja. ${ }^{31}$ Sementara isi dari ketentuan umum mudharabah untuk tabungan dan deposito sebagaimana fatwa DSN MUI, PBI dan SEBI semuanya sesuai ketentuan Pasal 26 ayat (1), (2) dan (3) Undang-Undang No. 21 Tahun 2008. ${ }^{32}$ Ketentuan

31 Ketentuan umum tabungan dan deposito mudharabah: 1) dalam transaksi ini nasabah bertindak sebagai shahibul maal atau pemilik dana dan bank bertindak sebagai mudharib atau pengelola dana, 2) Dalam kapasitasnya sebagai mudharib bank dapat melakukan berbagai macam usaha yang tidak bertentangan dengan prinsip syariah dan mengembangkannya termasuk di dalamnya mudharabah dengan pihak lain, 3) Modal harus dinyatakan dengan jumlahnya dalam bentuk tunai dan bukan piutang, 4) Pembagian keuntungan harus dinyatakan dalam bentuk nisbah dan dituangkan dalam akad pembukaan rekening, 5) Bank sebagai mudharib menutup biaya operasional tabungan dengan menggunakan nisbah keuntungan yang menjadi haknya, 6) Bank tidak diperkenankan mengurangi nisbah keuntungan nasabah tanpa persetujuan yang bersangkutan.

32

Pasal 26 ayat (1) menyatakan kegiatan usaha sebagaimana dimaksud dalam Pasal tersebut meliputi masalah posisi pemilik dana, pengelola dana, aturan dan tata cara pengelolaan dana, transaksi pembagian keuntungan, penarikan dana oleh pemilik dana dan biaya operasional.

Ketentuan tersebut dapat disimpulkan sebagai berikut :

1. Dalam tabungan dan deposito mudharabah pemilik dana bertindak sebagai nasabah atau shahibul mal, sementara bank bertindak sebagai pengelola dana atau mudharib dan dana yang disetorkan ke bank syariah secara penuh serta dinyatakan dalam jumlah nominal;

2. Pembuatan transaksi dilakukan berdasarkan kepada kesepakatan antara pihak nasabah dan pihak bank syariah yang meliputi batasan atau tanpa batasan pengelolaan seperti jenis atau macacm usaha yang dimintakan oleh nasabah, prosentase

19, Pasal 20 dan Pasal 21 dan/atau produk dan jasa syariah, wajib tunduk kepada prinsip syariah, ayat (2) menyatakan prinsip syariah sebagaimana dimaksud pada ayat (1) difatwakan oleh Majelis Ulama Indonesia dan ayat (3) menyatakan fatwa sebagaimana dimaksud pada ayat (2) dituangkan dalam Peraturan Bank Indonesia. 
Hermansyah

Jurnal Hukum Mimbar Justitia

Vol. 4 No. 1 - Juni 2018

pembagian keuntungan dan waktu penarikan dana;

3. Bank syariah tidak diperkenankan mengurangi bagian keuntungan nasabah atau shahibul mal tanpa adanya persetujuan dari nasabah yang bersangkutan.

4. Bank syariah diberikan wewenang untuk menerapkan biaya administrasi kepada nasabah berupa biaya yang terkait langsung dengan pengelolaan rekening seperti biaya materai, cetak laporan transaksi dan saldo rekening ataupun biaya penutupan rekening.

Pembiayaan merupakan pendanaan yang disediakan oleh satu pihak untuk pihak lain guna mendukung investasi baik yang dilakukan oleh sendiri maupun lembaga yang senantiasa berkaitan dengan aktivitas bisnis yaitu sebuah aktivitas yang mengarah kepada peningkatan nilai tambah melalui proses penyerahan jasa, perdagangan atau pengolahan barang produksi. Dalam perspektif UndangUndang No. 21 Tahun 2008 tentang Perbankan Syariah pembiayaan adalah penyediaan dana atau tagihan yang merupakan sebuah transaksi dengan menggunakan bagi hasil dalam bentuk mudharabah dan musyarakah. ${ }^{33}$

Penerapan prinsip bagi hasil dalam praktek bank syariah setidaknya membawa dampak yang positif serta memberikan perlindungan masyarakat khususnya terhadap pemilik dana yang menyimpan dananya di bank syariah. Hal ini dapat dilihat dengan adanya sistem pembagian usaha atas simpanan nasabah dengan menggunakan metode net revenue sharing atau metode profit sharing. Konsep yang diterapkan dalam praktek bank syariah sangatlah berbeda apabila dibandingkan dengan praktek yang berlaku pada bank konvensional yang menggunakan parameter bunga sebagai bentuk imbalan atas simpanan nasabahnya.

Dari uraian penulis dapat mengambil kesimpulan bahwa mudharabah yang dipahami oleh umat Islam sekarang ini mempunyai dua makna yaitu :

1. Mudharabah sebagai sebuah produk.

Makna yang terkadung dalam konteks mudharabah sebagai sebuah produk diterapkan dalam beberapa jenis

33 Atang Abd. Hakim, 2011, Fiqih Perbankan Syariah, Refika Aditama, Bandung, hIm. 219. 
Hermansyah

Jurnal Hukum Mimbar Justitia

Vol. 4 No. 1 - Juni 2018

pelayanan yang disediakan oleh bank syariah. Dalam kerangka ini mudharabah diterapkan dalam produk penghimpunan dana dan penyaluran dana atau pembiayaan. Produk penghimpunan dana ini meliputi tabungan mudharabah dan deposito mudharabah. Sementara penyaluran dana dalam bentuk pembiayaan dengan sistem mudharabah dan musyarakah. Produk penghimpunan dana di atur dalam Fatwa MUI-DSN No. 50/DSNMUI/III/2006, tentang akad mudharabah musytarakah yaitu salah satu bentuk akad mudharabah dimana bank syariah turut menyertakan modalnya dalam kerjasama investasi, diperlukan karena mengandung unsur kemudahan dalam pengelolaannya serta dapat memberikan manfaat yang lebih bagi para pihak. Sedangkan pembiayan mudharabah diatur dalam Fatwa Majelis Ulama Indonesia Dewan Syariah Nasional Nomor 7/DSNMUI/IV/2000.

2. Mudharabah sebagai sebuah sistem.

Dalam konteks ini mudharabah merupakan sebuah sistem dimana mudharabah menjadi pedoman umum bagi bank syariah dalam melakukan berbagai transaksi produk perbankan yang tersedia. Dengan sistem ini bank akan membagi keuntungan dengan para pengguna jasanya dan para investornya. Pada posisi ini mudharabah secara tepat dipahami sebagai pengganti dari sistem bunga.

Mudharabah menurut istilah diartikan sebagai pemilik harta atau modal menyerahkan modal kepada pengusaha untuk berdagang dengan modal tersebut dan laba dibagi di antara keduanya berdasarkan persyaratan yang disepakati. Apabila rugi hal itu ditanggung oleh pemilik modal dan pengusaha tidak bertanggungjawab atas kerugian tersebut. Kerugian pengusaha hanyalah dari segi kesungguhan dan pekerjaannya yang tidak akan mendapatkan imbalan. ${ }^{34}$

Penggunaan metode net revenue sharing terhadap bagi hasil atas simpanan nasabah pada bank syariah, apabila dihubungkan dengan praktek perbankan di masa Rasulullah dan sahabat sangatlah bertentangan, karena pada masa itu yang dipergunakan adalah metode profit sharing atau bagi untung.

34 Rachmat Syafei, 2000, Fiqih Muamalah, Pustaka Setia, Bandung, hlm. 224. 


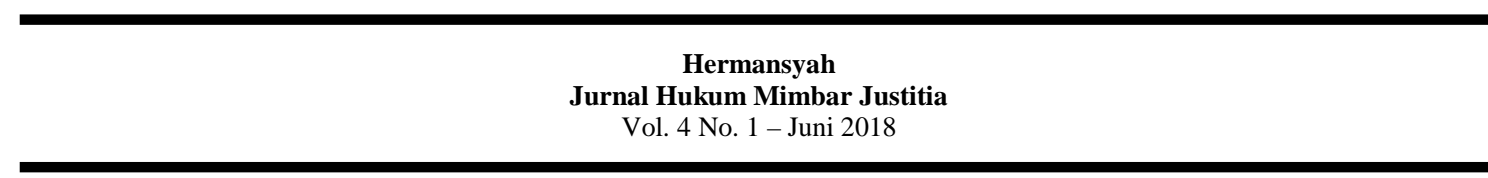

Apabila kita kaitkan dengan bunyi

Fatwa DSN diatas kemaslahatan pada saat ini, maka ini bisa diartikan sebagai suatu hal yang darurat yaitu apabila dipaksakan untuk menerapkan metode profit sharing akan berakibat terpuruknya bank syariah. Hal ini bisa kita kaji berdasarkan kaidah fiqih sebagai berikut :

“ Tidak ada keharaman beserta darurat dan tidak ada kemakruhan bersama kebutuhan."

Kaidah ini menjadikan hal-hal yang tadinya makruh tetapi karena dibutuhkan oleh manusia, maka hilanglah kemakruhan itu untuk sementara waktu selama keadaan darurat dan kebutuhan itu masih berlaku. Kaidah fiqih yang lainnya yaitu: "Menolak kerusakan harus didahulukan daripada menarik kemaslahatan". Kandungan kaidah fiqih ini menjelaskan bahwa jika terjadi perlawanan antara kerusakan dan kemaslahatan pada suatu perbuatan, mengandung kerusakan dan kemaslahatan maka segi larangannya yang harus didahulukan.

\section{Menurut Muhammad Syafi'i}

Antonio, berdasarkan prinsip mudharabah bank syariah akan berfungsi sebagai mitra baik dalam simpanan nasabah maupun dengan peminjam dana. Dalam hubungan dengan penyimpan dana (simpanan nasabah) bank bertindak sebagai mudharib atau pengelola sedangkan masyarakat pemilik dana bertindak sebagai shahibu maal. Sementara hubungannya dengan masyarakat peminjam bank bertindak sebagai shahibul maal dan masyarakat peminjam dana sebagai mudharib. Dalam penghimpunan dana dengan menggunakan prinsip mudharabah mutlaqah, kedudukan bank syariah sebagai shahibul maal (pemilik dana) sedangkan sebagai pengelola dana (mudharib) adalah debitur. Sedangkan yang dimaksud dengan mudharabah muqayyadah adalah pemilik dana (shahibul maal) membatasi/memberi syarat kepada mudharib (pengelola). ${ }^{35}$

Dalam penghimpunan dana dengan prinsip mudharabah muqayyadah ini kedudukan bank syariah hanya sebagai agen saja karena pemilik dana (shahibul maal) adalah nasabah. Kenyataannya di lapangan

35 Muhammad Syafi'i Antonio, 2001, Bank Syariah;Dari Teori Ke Praktik, Gema Insani, Jakarta, hlm. 137. 
Hermansyah

Jurnal Hukum Mimbar Justitia

Vol. 4 No. 1 - Juni 2018

penerapan sistem bagi hasil oleh bank syariah atas simpanan masyarakat secara umum menggunakan metode bagi hasil secara revenue sharing belum ada yang menggunakan metode bagi hasil secara pembagian laba (profit sharing). Menurut Haron and Norafifah, which states that the rate of profit-sharing savings positive effect on the amount of savings deposits in Islamic banks. ${ }^{36}$

Gambar. 1. Perbedaan prinsip antara sistem bagi hasil revenue sharing dan profit sharing ${ }^{37}$

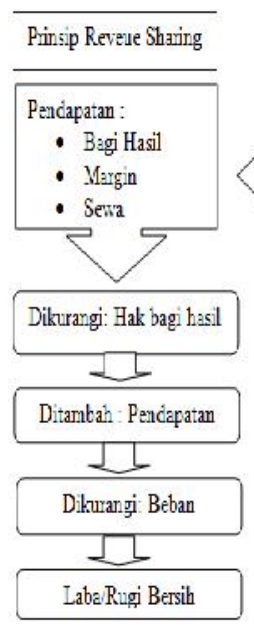

Apabila
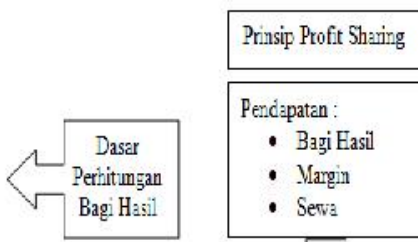

enciapatan

- Bıgi Hasil

- Margir

- Seva
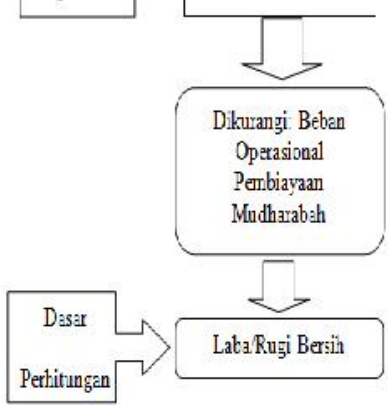

bank usaha dengan pembagian hasil (net revenue sharing), maka semua beban yang dikeluarkan oleh bank syariah menjadi tanggungan bank syariah sendiri sehingga tidak diperhitungkan dalam unsur distribusi hasil usaha. Apabila bank syariah mempergunakan prinsip pembagian untung (profit sharing) maka bank syariah harus dapat membedakan dengan jelas, transparan dan adil terhadap beban-beban yang yang merupakan pengurang dari pendapatan pengelolaan dana mudharabah (yang disebut dengan beban dana mudharabah) dan bebanbeban yang merupakan pengeluaran bank syariah. Semua beban dana mudharabah tersebut termasuk beban tenaga kerja, beban umum dan administrasi serta beban-beban lainnya. $^{38}$

Penggunaan metode net revenue sharing maupun metode profit sharing dalam pembagian hasil usaha terhadap simpanan nasabah mudharabah pada bank syariah diperbolehkan. Bahwa untuk kemaslahatan saat ini maka bank syariah dalam melakukan perhitungan

38 Wiroso, 2005, Penghimpunan Dana dan Distribusi Hasil Usaha Bank Syariah, Gramedia Widiasarana Indonesia, Jakarta, hlm. 128. Salemba Empat, Jakarta, hlm. 372. 
Hermansyah

Jurnal Hukum Mimbar Justitia

Vol. 4 No. 1 - Juni 2018

untuk pembagian hasil usaha sebaiknya menggunakan metode revenue sharing, tetapi dengan beberapa catatan diantaranya adalah sebagai berikut: pola pikir kapitalisme yang selalu mengukur setiap simpanan dananya di bank dengan ukuran uang.

\section{PENUTUP}

A. Kesimpulan

Dalam Fatwa Dewan Syariah Nasional Majelis Ulama Indonesia Nomor 15 Tahun 2000 tanggal 16 September 2000 tentang Prinsip Distribusi Hasil Usaha Dalam Lembaga Keuangan Syariah, disebutkan bahwa pembagian hasil usaha di antara para pihak (mitra) dalam suatu bentuk usaha kerjasama dengan prinsip mudharabah, boleh didasarkan pada prinsip bagi untung (profit sharing) dan boleh pula didasarkan pada prinsip bagi hasil (net revenue sharing). Profit sharing adalah metode bagi hasil yang basis perhitungannya adalah dari profit yang diterima oleh bank. Sedangkan yang dimaksud dengan net revenue sharing adalah metode bagi hasil yang basis perhitungannya adalah pendapatan bank.

Implementasi metode bagi hasil prinsip mudharabah apabila dihubungkan dengan Fatwa Dewan Syariah Nasional Nomor. 15/DSN- 
MUI/IX/2000 tentang prinsip distribusi hasil usaha pada bank syariah di Indonesia, yang dipergunakan adalah metode net revenue sharing pada saat bank syariah berperan sebagai mudharib dan nasabah investor sebagai shaibul maal, sedangkan pada saat bank syariah sebagai shahibul maal metode yang dipergunakan adalah profit sharing.

\section{B. Saran}

Sehubungan dengan sifat fatwa yang dinamis yaitu berubah sesuai dengan situasi dan kondisi, maka Fatwa MUI-DSN No. 15/MUI-DNS/2002 tentang metode net revenue sharing dan metode profit sharing, menurut penulis harus diamandemen dikarenakan penerapan kemaslahatan untuk saat sudah saatnya dipertegas dimana pembelakuan atau pengertian untuk kemaslahatan saat ini harus dibatasi sampai kapan fatwa tersebut berlaku.

Dalam implementasi metode bagi hasil dengan prinsip mudharabah untuk memberikan rasa keadilan maka harus diupayakan semaksimal mungkin mengaplikasikan metode profit sharing khususnya dalam sistem pembagian hasil usaha terhadap simpanan nasabah pada bank syariah di Indonesia.

\section{DAFTAR ISI}

\section{A. Buku}

Ali Hasan, 2010, Marketing Bank Syariah, Ghalia Indonesia, Bandung.

Atang Abd. Hakim, 2011, Fiqih Perbankan Syariah, Refika Aditama, Bandung.

Hamid Arfin, 2007, Hukum Ekonomi Islam (Ekonomi Syariah) Indonesia, Ghalia Indonesia, Makasar.

Hulwati, 2006, Ekonomi Islam, Ciputat Press, Jakarta.

Izzudin bin Abd al-Salam, 2006, Qawa'id al-Ahkam fi Mashalih alAnam, (t.t.:Daral-Jail), Juz I, hlm.11 dalam H.A. Djazuli, Kaidah-Kaidah Fiqih, Kencana Prenada Media Group, Jakarta.

M. Syafi'i Antonio, 2001, Bank Syariah; Dari Teori ke Praktik, Jakarta, Gema Insani.

Muhammad Yusuf, Wiroso, 2011, Bisnis Syariah, Jakarta, Mitra Wacana Media.

Muhammad, 2002, Manajemen Bank Syari'ah, (UPP) AMP YKPN, Jogjakarta.

Muhammad, 2008, Manajemen Pembiayaan Mudharabah di Bank Syariah, RajaGrafindo, Jakarta. 
Osmad Muthaher, 2012, Akuntansi Perbankan Syariah, Yogyakarta, Graha Ilmu.

Rachmat Syafei, 2000, Fiqih Muamalah, Bandung, Pustaka Setia.

Rizal Yahya, Aji Erlangga, Ahim Abdurahim, 2009, Akuntansi Perbankan Syariah; Teori dan Praktik Komtemporer, Salemba Empat, Jakarta.

Umi Karomah Yaumiddin, 2010, Usaha Bagi Hasil Antara Teori Dan Praktek, Kreasi Wacana, Bantul.

Veithzal Rivai, Andi Buchari, 2009, Islamic Economics; Ekonomi Syariah Bukan Opsi Tetapi Solusi, Bumi Aksara, Jakarta.

Wiroso, 2005, Penghimpunan Dana dan Distribusi Hasil Usaha Bank Syariah, PT. Gramedia Widiasarana Indonesia, Jakarta.

Yusuf Qardhawi, 2007, Halal Haram Dalam Islam, Era Intermedia.

\section{B. Peraturan Perundang- Undangan}

Undang-Undang Dasar 1945.

Undang-Undang No. 21 Tahun 2008, Tentang Perbankan Syariah.

Undang-Undang No. 10 Tahun 1998 Tentang Perbankan.

Peraturan Bank Indonesia No. 7/46/PBI/2005, tentang Akad Penghimpunan Dan Penyaluran Dana Bagi Bank Yang
Melaksanakan Kegiatan Usaha Berdasarkan Prinsip Syariah.

Peraturan Bank Indonesia No 9/19/PBI/2007, tentang pelaksanaan prinsip syariah dalam kegiatan penghimpunan dana dan penyaluran dana serta pelayanan jasa bank syariah.

Surat Edaran Bank Indonesia No. 10/14/DPbs, tentang Pelaksanaan Prinsip Syariah dalam Kegiatan Penghimpunan Dana dan Penyaluran Dana serta Pelayanan Jasa Bank Syariah tanggal 17 Maret 2008.

Fatwa No. 2/DSN-MUI/IV/2000 tanggal 1 April 2000 tentang Tabungan Mudharabah.

Fatwa No. 3/DSN-MUI/IV/2000 tanggal 1 April 2000 tentang Deposito Mudharabah.

Fatwa MUI-DSN No. 7/DSNMUI/IV/2000, Tentang Akad Mudharabah.

Fatwa DSN No.15/DSN-MUI/IX/2000 tentang Prinsip Distribusi Hasil Usaha Dalam Lembaga Keuangan Syariah.

Fatwa MUI-DSN No. 50/DSNMUI/III/2006, tentang akad mudharabah musytarakah

C. Jurnal, Makalah, Internet dan Lain-lain.

Achmad Baraba, 1999, Prinsip Dasar Operasional Perbankan Syariah, Buletin Ekonomi Moneter dan Perbankan, Vol. 2 No. 3. 
Hermansyah

Jurnal Hukum Mimbar Justitia

Vol. 4 No. 1 - Juni 2018

Dwi Agung Nugroho Arianto, 2011, Peranan Al Mudharabah Sebagai Salah Satu Produk Perbankan Syariah Dalam Upaya Mengentaskan Kemiskinan Di Indonesia, Jurnal Ekonomi \& Pendidikan, Volume. 8 Nomor. 2, Edisi November.

Hermansyah, Sandi Rizki Febriadi, 2017, Implementasi Akad Mudharabah Pada Bank Syariah Dihubungkan Dengan Pasal 1338 KUH Perdata, Prosiding SNaPP Sosial, Ekonomi dan Humaniora, Vol 7, No.2, Oktober.

Iim Hilman, 2016, The Factors Affecting Mudharabah Deposits of Sharia Banking in Indonesia, International Journal of Business and Management Invention, Vol. 5, Issue. 8, Ed. Agustus.

Mia Amalia, 2016, Analisis Terhadap Tindak Pidana Prostitusi Dihubungkan Dengan Etika Moral Serta Upaya Penanggulangan Dikawasan Cisarua Kampung Arab, Jurnal Hukum Mimbar Justitia Fakultas Hukum Universitas
Suryakancana, Vol. 2, No. 2, Edisi Desember.

Toto T Suriaatmadja, 2004, Kontribusi Hukum Islam Dalam Pembentukan Hukum Nasional Menuju Masyarakat Madani, Jurnal Syiar Madani, Vol. 6, No. 1.

Setiawan Budi Utomo, 2011, Kajian Hukum Atas Keabsahan Produk Perbankan Syariah Dikaitkan Dengan Fatwa DSN Dalam Tujuan Negara Keadilan, Disertasi, Fakultas Hukum Unpad.

Tawfique Al-Mubarak, Noor Mohammad Osmani, 2010, Applications of Maqasid alShari'ah and Maslahah in Islamic Banking practices: An analysis, International Seminar on Islamic Finance in India, Kochi, India, October.

Walim, 2017, Prinsi, Asas dan Kaidah Hukum Waris Islam Adil Gender, Jurnal Mimbar Justitia Fakultas Hukum Universitas Suryakancana, Vol. 3, No. 1, Edisi Juni. 